\title{
SANITARY OBJECTS EVACUATION WITH PRESENCE OF IMMOBILE OCCUPANTS
}

Radoje Jevtić ${ }^{1}$

\section{ЕВАКУАЦИЈА ЗДРАВСТВЕНИХ ОБЈЕКАТА СА ПРИСУСТВОМ НЕПОКРЕТНИХ ОСОБА}

Радоје Јевтић

\section{Summary}

Many different sanitary objects, such as ambulances, hospitals, emergencies, convalescent and rehabilitation objects, clinics and other objects with the similar purposes imply nonstop presence of great number of people, where many of them can be immobile. Their accommodation, movement and functioning can be problematic even in the normal conditions while in the cases of some exceptional circumstances, such as fire, earthquake, water flow, terrorism attack or similar that can be very hard and complex. One of, in the technical and safe sense, the hardest occurrence for that object's type is a complete occupants evacuation on the safe and secure place. This paper was written to show the importance of evacuation prediction with proper usage of computer software in the simulation of evacuation of sanitary object with presence of immobile occupants-patients.

Key words: evacuation, immobile, simulation, sanitary object.

\section{Сажетак}

Многи различити здравствени објекти као што су амбуланте, болнице, хитне помоћи, објекти за рехабилитацију и опоравак, клинуке и други објекти са сличним наменама подразумевају непрестано присуство великог броја људи где многи од юих могу бити непокретни. Њихов смештај, кретање $и$ функционисање може бити проблематично чак и у нормалним условима док у посебним околностима, као што су ватра, земљотрес, поплава, терористички напад или слично могу бити веома тешки и комплексни. Један од, у техничком и сигурносном смислу, најтежих догађаја за објекат тог типа је комплетна евакуащија окупаната на сигурно и безбедно место. Овај рад је написан да покаже важност предвиђања евакуачије са одговарајућом употребом компјутерског софтвера у симулачији евакуачије здравственог објекта са присуством непокретних окупаната - nаџијената.

Кључне речи: евакуачија, непокретан, симулација, здравствени објекат.

\footnotetext{
${ }^{1}$ Radoje Jevtić, PhD in technical sciences, School for electrical engineering "Nikola Tesla“, Nis, Serbia (Др Радоје Јевтић, дипломирани инжењер електротехнике, ЕТШ „Никола Тесла“, Ниш, Србија).
} 


\section{INTRODUCTION}

$\mathrm{S}$ anitary objects, particularly hospitals and clinic centres were designed and built by non-combustible materials.

Very often, those objects were arranged as one or, what is more often case, several separated buildings or objects, between connected with outer or underground hallways.

The inner arrangement in sanitary objects is appropriate to corridor building system. This system implies that all rooms are linked to one base communication route.

Sanitary objects, related to their purposes, comprehend many different rooms: ordinations, patient rooms, laboratories, receptions, lobbies, shock rooms, special technical rooms, medical rooms, halls, storages and many others. Many of them comprehend sensitive electrical devices (scanners, magnetic resonance, ultrasound devices and others), different chemicals, medicaments, oxygen bottles and lot of different medical and no medical stuff.

Patients in sanitary objects are stationed in rooms, in ordinary beds or medical beds. They can move on their own or with assistance. The evacuation of sanitary objects can be very complicated so it should be only in the case when the situation demands. The evacuation must be realized with assistance of medical personnel and with usage of evacuation routes. The evacuation of infective part of sanitary object demands special procedures, with professional medical personnel assistance, in order to stop the potential of contamination spreading. Reasons for evacuation could be different, as it was noted: fire, earthquake, water flow, terrorism, tornado, whirlwind, tsunami or else.

Fire presents one of the biggest dangers for every object with lot of humans, especially if many of them are immobile or need assistance for movement. The most common way of fire spreading in sanitary object is through combustible materials located inside. Wood, parts of windows, doors, and other construction materials can burn. The rest of combustible materials could cause spreading of fire products through the stairs, what would probably cause with fear and panic on patients. In those cases, the endangered parts of sanitary object must be found by careful patrol, quiet and without patient's rooms entering. In the case of huge fire, all available forces should be activated. In those cases, evacuation can be realized by some very effective instruments: hydraulic mechanical platform, ladders or others. In the cases with fire, the extinguishing should be realized with usage of water fog and, for chemicals and electrical devices, with dust, carbon dioxide and foam. The complete extinguishing and evacuation actions must be realized very carefully, very fast and safe..$^{(1-4)}$

Some examples of fire in sanitary objects are presented on figures 1 and 2 (fire in Calcutta Medical College on October 3, 2018 and hospital and fire in hospital in Istanbul on April $6,2018){ }^{(5,6)}$

Figure 1. Fire in Calcutta Medical College and Hospital (figure source: https://www. thehindubusine ssline.com/multimedia/photo/ in-pictures-fire-breaks-out-in-calcutta-medicalcollege-and-hospital/article 25109821.ecel photo/4/).

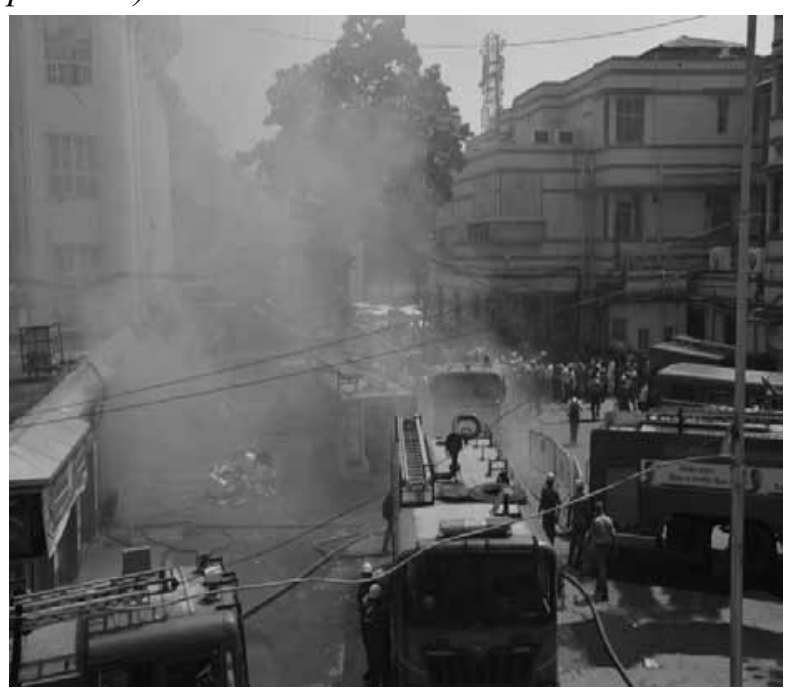


Figure 2. Huge fire in hospital in Istanbul (figure source: https://www.news.com.au/world/ middle-east/ major-fire-breaks-out-at-hospitalin-istanbul-turkey-patients-evacuated/newsstory/0b4ef abde0ff457610a5f2b33b2509d0).

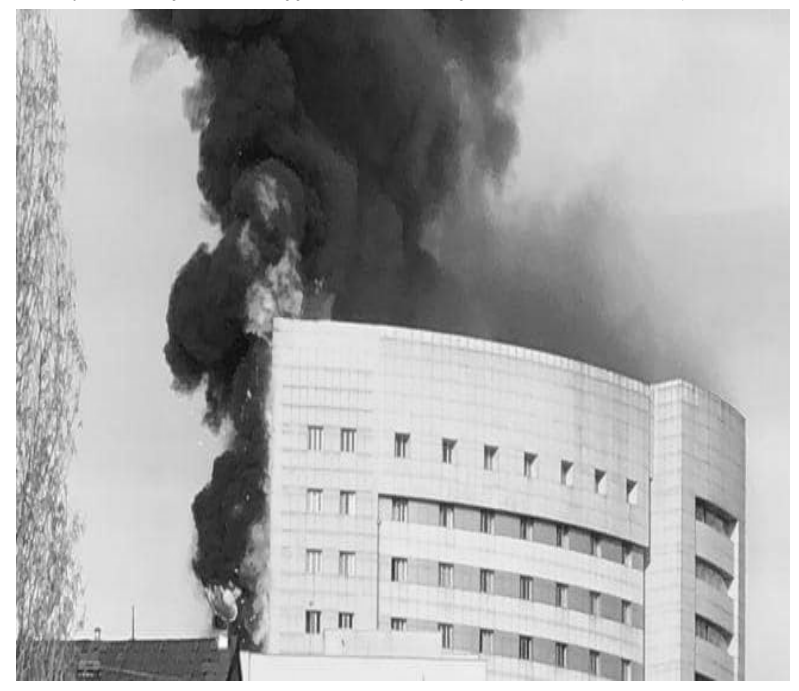

Earthquake also can be the reason for sanitary object evacuation. Those events are especially hard and complex for evacuation because earthquake usually destroys big number of objects and big surfaces and the approach to the injured people is, very often, impossible without assistance of big number of rescuers with specially trained dogs and mechanisation. Earthquake also can cause the tsunami that can cause a great damage also. Huge earthquake, as example, that occurred in Mexico in September 19, 2017 took a lot of victims. Beside many objects and buildings (according to available resources over 40 buildings were totally crashed) several hospitals were destroyed. ${ }^{(7)}$ Destructions caused by earthquakes sometimes can be so huge that rescuers can't reach endangers for days and weeks. The lack of food and water, basic supplies and others also can have great influence on evacuation in such cases.

As an example, the evacuation of patients from hospital after a massive 8.6-magnitude earthquake on Sumatra is presented on figure $3 .{ }^{(8)}$
Figure 3. Evacuation of patients from hospital on April 11, 2012 after a massive 8.6-magnitude earthquake in Banda Aceh, in Aceh province, on Sumatra (figure source: https://www.thehindu. $\mathrm{com} / \mathrm{sci}$-tech/energy-and-environment/New-faultin-Indian-Ocean-may-trigger-quakes-in-futurestudy/article17013186.ece).

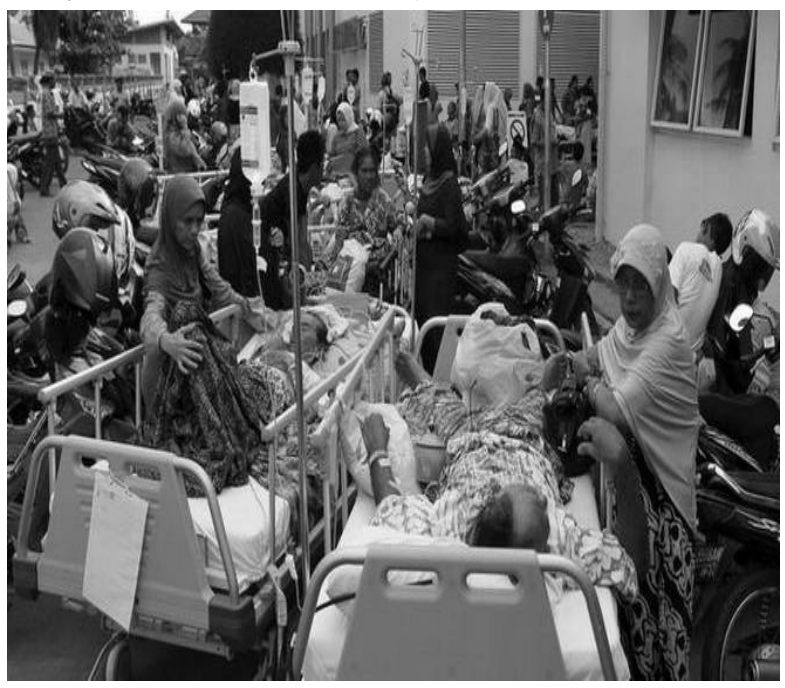

Massive water flows are also reason for evacuation, but this reason can be somehow predicted so that adequate services can prepare themselves and appease the consequences.

According to above noted facts, the evacuation of hospital presents very hard and complex task no matter what was the cause for evacuation. This task is even harder and complicated when the evacuation is related to immobile patients. Immobile patients can be sited in medical beds and wheelchairs. Immobile patients in wheelchairs sometime can push their wheelchairs without assistance and sometime not for their movement while patients in medical beds always need assistance for moving. Things are much complicated under evacuation-moving of beds and wheelchairs via ordinary or emergency stairs can be possible but very difficult and slow. Crowds and jams that can be occurred in these situations are very difficult to solve. This paper was written to show the potential usage of simulation software for prediction of possible evacuation scenarios-situations and to calculate needed time for evacuation in those situations. 


\section{SIMULATION MODEL}

Simulation model used in this paper was realised in Pathfinder, version 2018. This software was specially design software tool for engineers and others who work with evacuation. Beside pure calculation, it has a powerful graphic interface that enables visual results and analyse. ${ }^{(9)}$

The simulated object presents hospital with five floors. The base dimensions were $47 \mathrm{~m}$ $\mathrm{x} 11 \mathrm{~m}$. The height of every floor was $3 \mathrm{~m}$, so the height of the object was $16 \mathrm{~m}$ (the thickness of every floor was $0.2 \mathrm{~m}$ ). Every floor has ten rooms with dimensions $4 \mathrm{~m} \times 4 \mathrm{~m} \times$ $3 \mathrm{~m}$. The width of the room doors was $120 \mathrm{~cm}$. There were ordinary stairs, emergency stairs and elevators between every floor. Ordinary stairs were realised as double, with width of $120 \mathrm{~cm}$ and they were located near elevators. Emergency stairs were located at the side of the object with width of $120 \mathrm{~cm}$. There were five elevators in the object, two bigger with dimensions $2,5 \mathrm{~m} \times 1,8 \mathrm{~m}$ and three smaller with dimensions $1,5 \mathrm{~m} \times 1 \mathrm{~m}$. The speed of bigger elevators was $0.7 \mathrm{~m} / \mathrm{s}$, for every elevator, while the speed for smaller elevators was $1,1 \mathrm{~m} / \mathrm{s}$ for every elevator. There were two potential exits where doors were with length of $200 \mathrm{~cm}$ - one exit presents main entrance - exit to the object while the other exit is an emergency exit.

The complete number of occupants was 285 . There were 125 doctors, medical assistances and mobile patients, while 160 occupants - patients were immobile. All of them were in wheelchair and they were located in rooms at every floor (32 immobile patients by floor). Doctors, assistances and other non-medical personnel (35 altogether) were located in every floor and in the rest of rooms. Number of patients in rooms can be two or three. There were 100 rooms attended for patients -20 per every floor (from the first floor to the fifth floor) while the rest of floors at the basement were attended for medical personnel and other purposes.

The complete simulation object in Pathfinder software, is presented on figure 4 (from the front) while the same object from the side is presented on figure 5 .

Figure 4. Pathfinder simulation model presentation (from the front of the object).

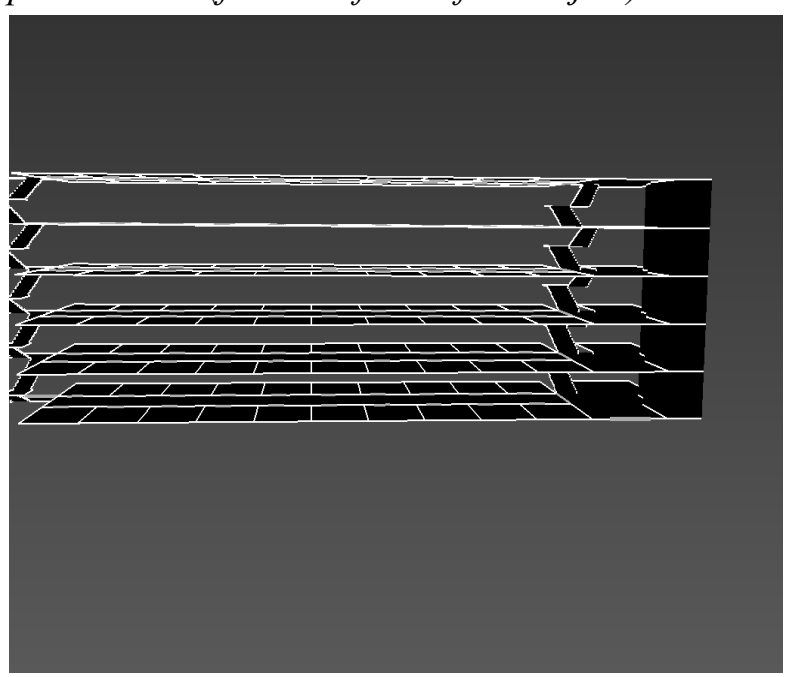

Figure 5. Pathfinder simulation model presentation (from the side of the object).

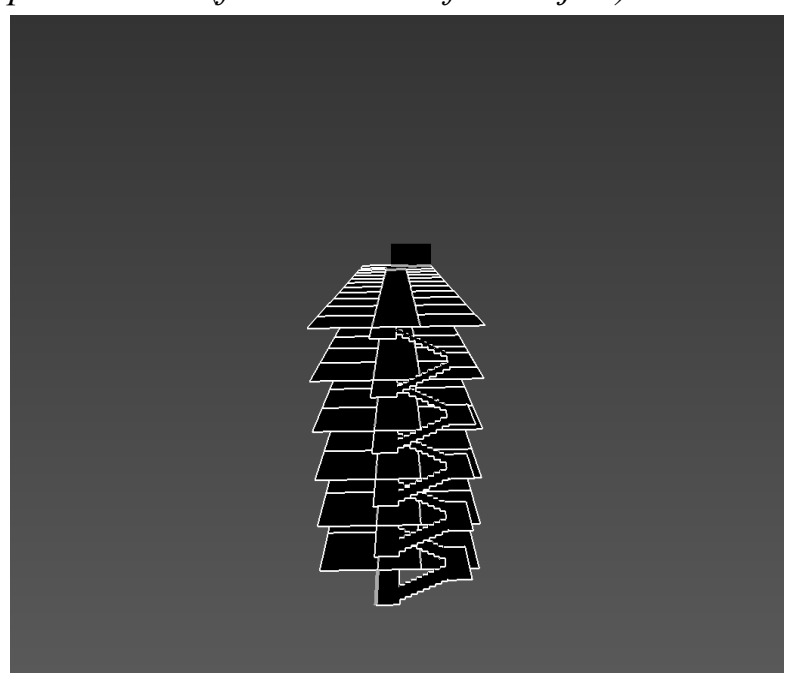

The simulation objects presented on figures 4 and 5 were presented with stairs, elevators, floors, emergency stairs and exits.

Many indifferent objects such as desks, chairs, closets, medicine chest and other objects were hidden by HIDE function for better view of simulation model. There were four different scenarios analysed.

The first scenario implied evacuation of all occupants only by usage of ordinary stairs. The second scenario implied evacuation of all occupants only by emergency stairs. 
The third scenario implied evacuation only by usage of elevators and ordinary stairs. The fourth scenario implied evacuation only by usage of ordinary stairs and emergency stairs at the same time.

For every of four scenarios, the speeds of mobile occupants were $1,2 \mathrm{~m} / \mathrm{s}, 1,5 \mathrm{~m} / \mathrm{s}, 2 \mathrm{~m} / \mathrm{s}$ and $2,5 \mathrm{~m} / \mathrm{s}$ while the speeds of immobile occupants were for wheelchairs $0,69 \mathrm{~m} / \mathrm{s}$. The dimensions of wheelchair was $1,25 \mathrm{~m} \times 0,75 \mathrm{~m}$. Pathfinder simulation model of wheelchair is presented on figure 6 .

Figure 6. Simulation model of wheelchair.

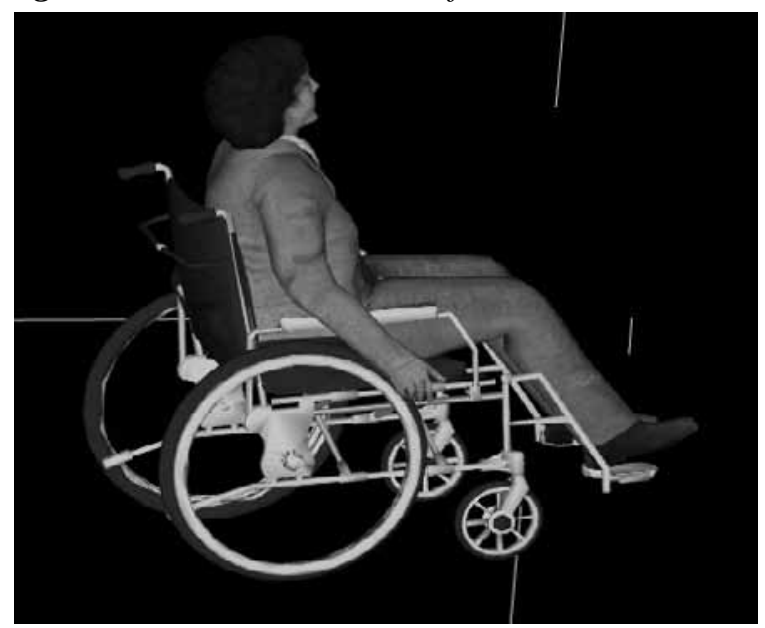

It is important to note that the presumption was that all of patients in wheelchair have ordinary mechanical wheelchairs which presumed evacuation speed was determined of $0,69 \mathrm{~m} / \mathrm{s}$ while electrical wheelchairs have presumed evacuation speed of $0,89 \mathrm{~m} / \mathrm{s}$. The assistance for wheelchairs by other mobile occupants was mostly at stairs..$^{(10,11)}$

\section{SIMULATION RESULTS}

The results for the purposes of this paper were realized on laptop HP with Intel ${ }^{\circledR}$ Core $^{\mathrm{TM}}$ i3 $6006 \mathrm{U}$ processor at $2.0 \mathrm{GHz}$ and with $4 \mathrm{~GB}$ of RAM. Maximal simulation time was set on 4500 seconds. Some of simulation moments from different scenarios are presented on figures from 7 to 11 while the complete simulation results showed on figures from 12 to 15 .
Figure 7. The moment of evacuation at the second floor for the second scenario and for mobile occupants speed of $2,5 \mathrm{~m} / \mathrm{s}$.

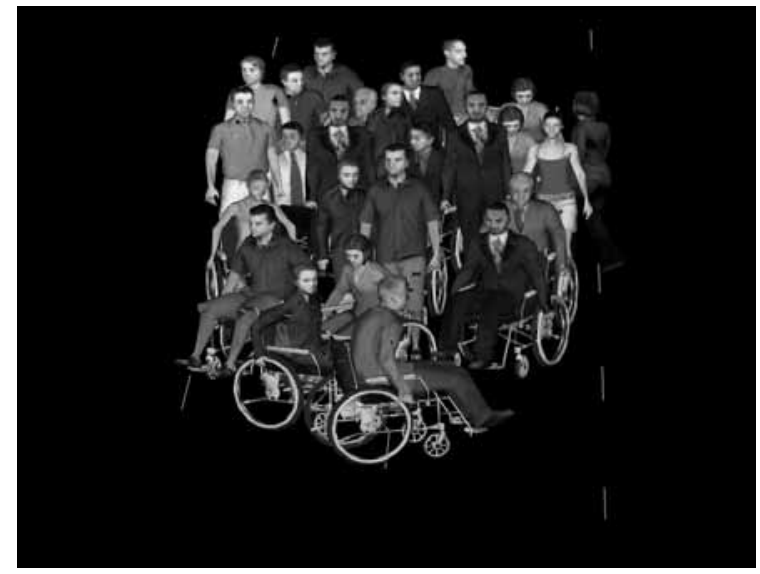

Figure 8. The moment of evacuation at the second, the first and the base floor for the first scenario and for mobile occupants speed of 1,5 $\mathrm{m} / \mathrm{s}$.

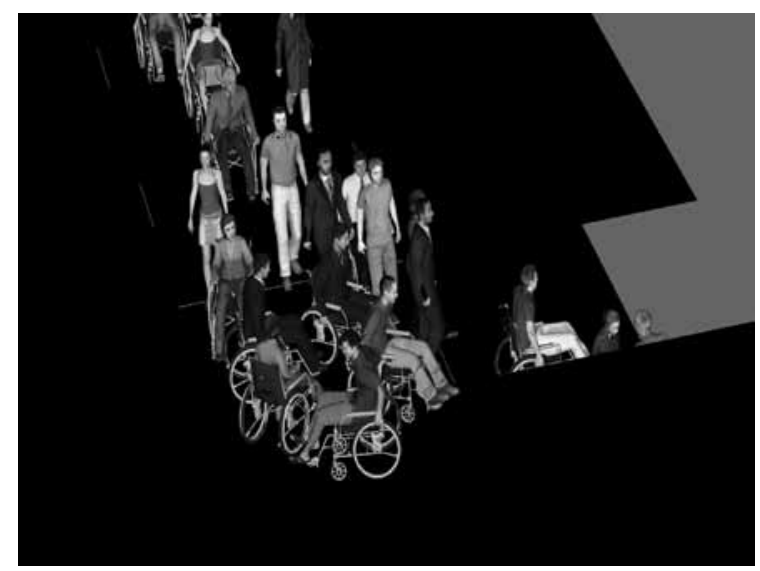

Figure 9. The moment of evacuation at the first and floor for the first scenario and for mobile occupants speed of $2 \mathrm{~m} / \mathrm{s}$.

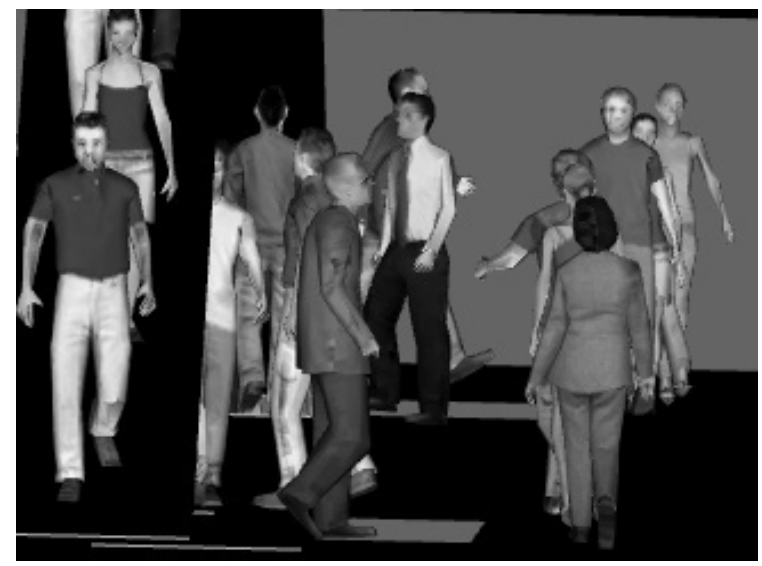


Figure 10. The moment of evacuation at the fourth floor for the third scenario and for mobile occupant's speed of $1,2 \mathrm{~m} / \mathrm{s}$.

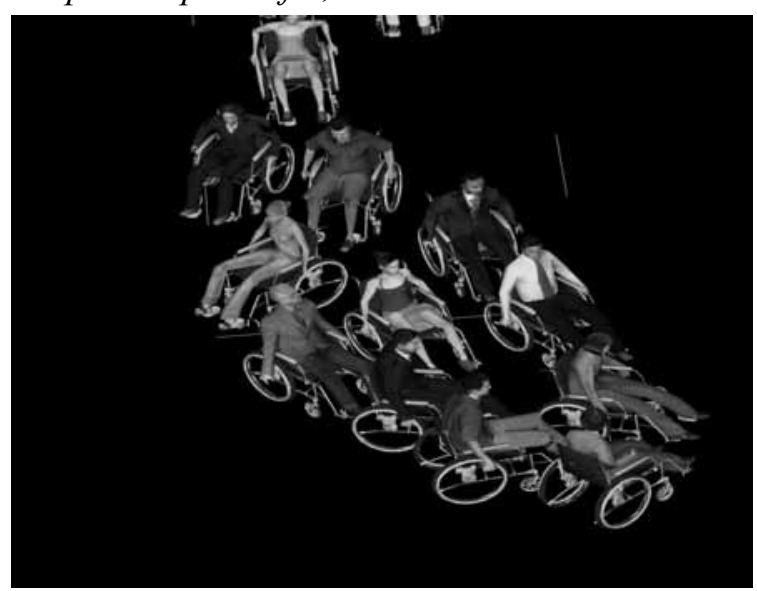

Figure 11. The moment of evacuation from the third scenario at ordinary stairs.

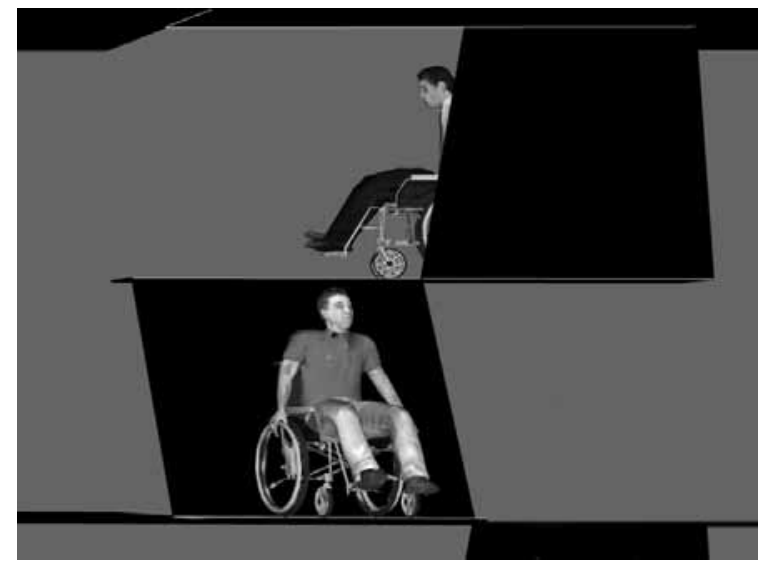

Figure 12. The complete simulation results for the first scenario.

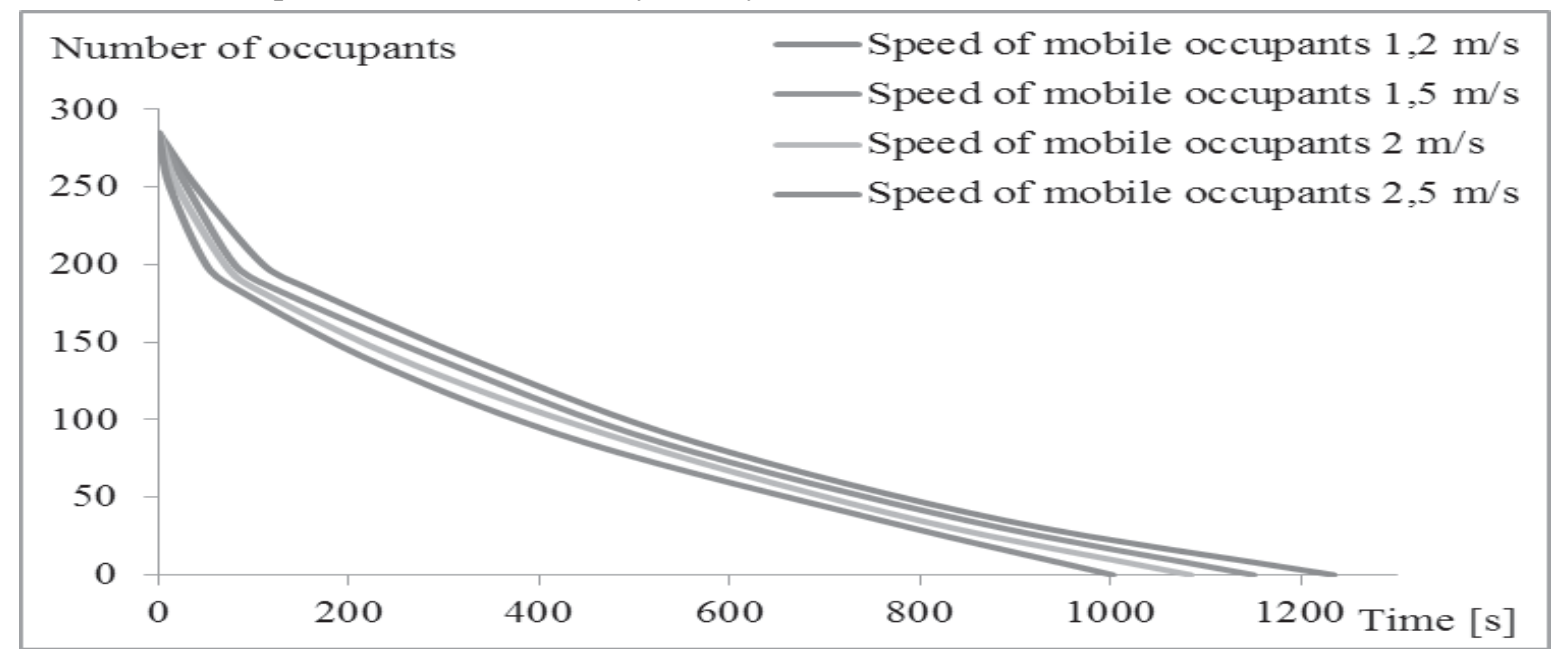

Figure 13. The complete simulation results for the second scenario

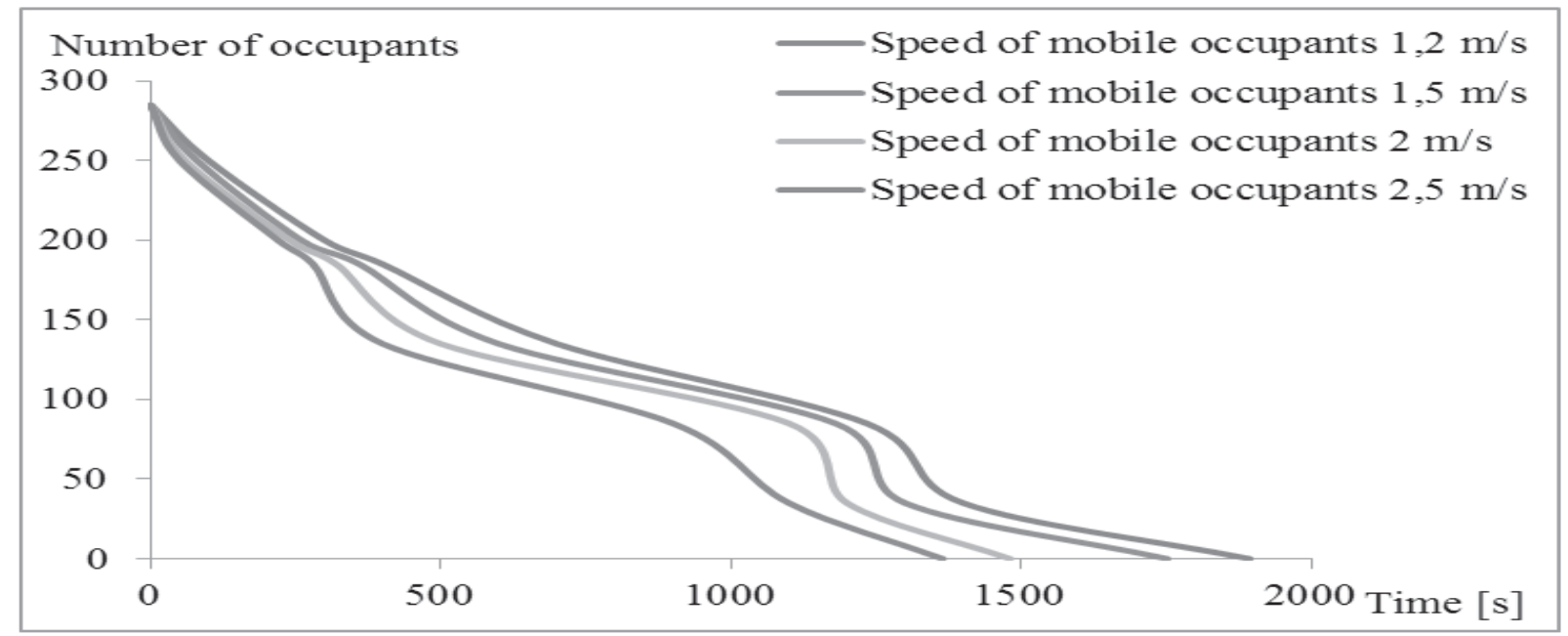


Figure 14. The complete simulation results for the third scenario.

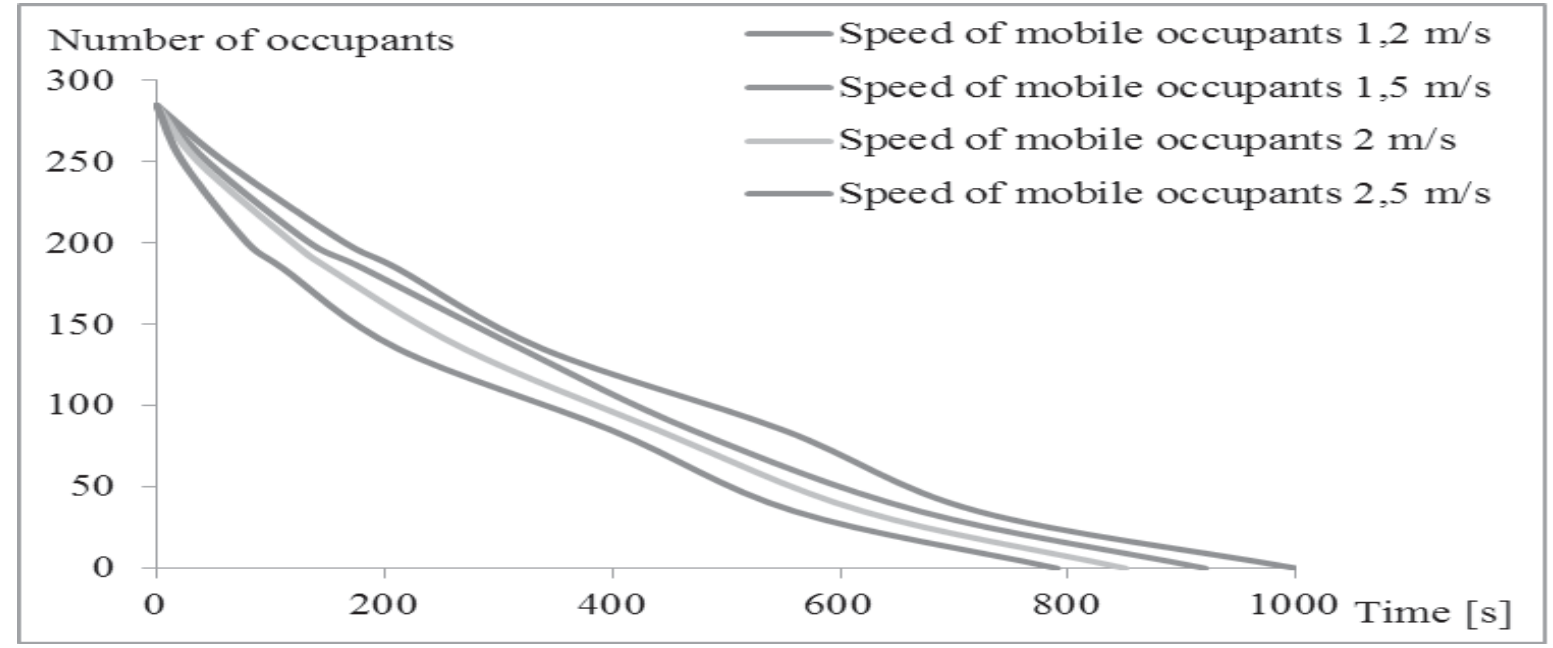

Figure 15. The complete simulation results for the fourth scenario

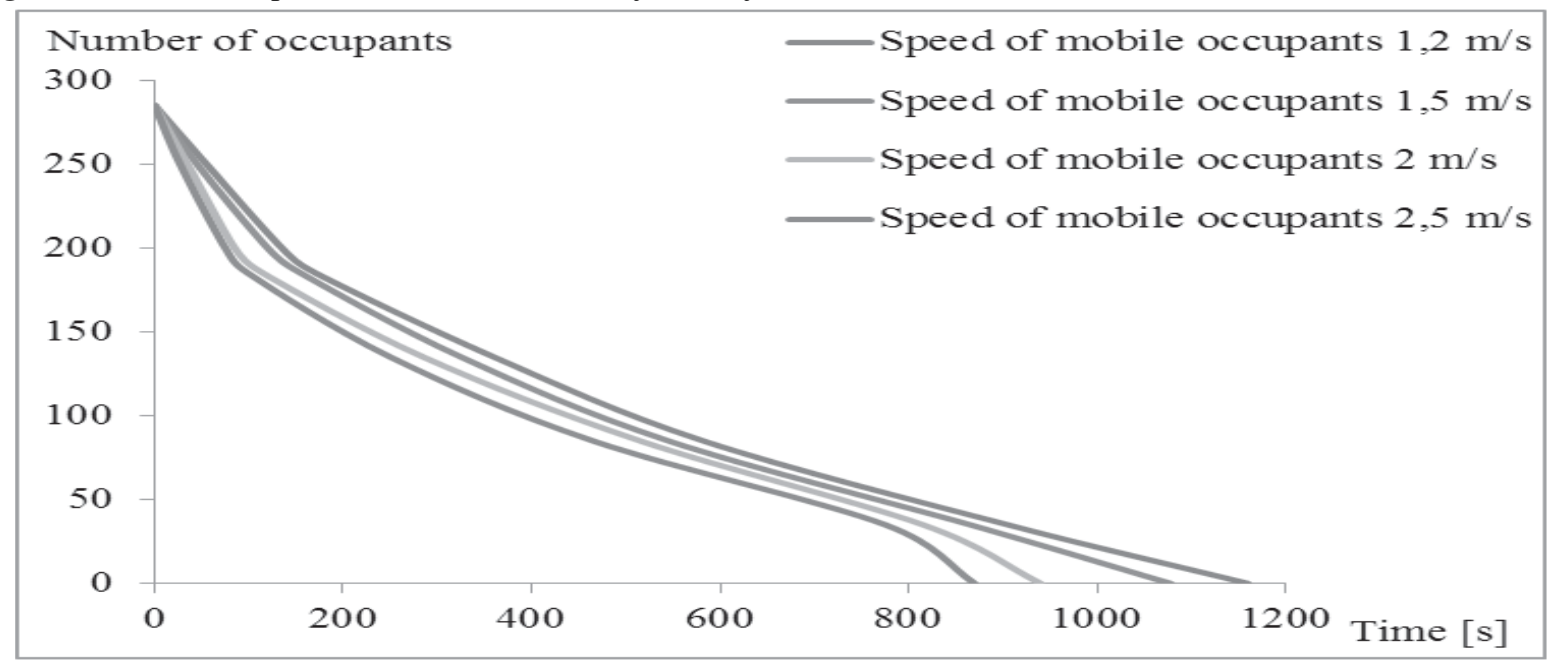

\section{RESULTS ANALYSE}

Simulation results showed on figure 12 for the first scenario that evacuation times were from 1234,12 seconds for the occupants speed of $2,5 \mathrm{~m} / \mathrm{s}$ to 1002,09 seconds for the occupants speed of $1,2 \mathrm{~m} / \mathrm{s}$. Simulation results showed on figure 13 for the second scenario that evacuation times were from 1895,4 seconds for the occupants speed of $2,5 \mathrm{~m} / \mathrm{s}$ to 1365,23 seconds for the occupants speed of $1,2 \mathrm{~m} / \mathrm{s}$. Simulation results showed on figure 14 for the third scenario that evacuation times were from 1000,87 seconds for the occupants speed of $2,5 \mathrm{~m} / \mathrm{s}$ to 790,91 seconds for the occupants speed of $1,2 \mathrm{~m} / \mathrm{s}$. Simulation results showed on figure 15 for the fourth scenario that evacuation times were from 1160,39 seconds for the occupants speed of $2,5 \mathrm{~m} / \mathrm{s}$ to 870,52 seconds for the occupants speed of $1,2 \mathrm{~m} / \mathrm{s}$.

The potentials for jams for every scenario appeared for any of analysed occupants speeds when the speed of wheelchairs was bigger than $0,85 \mathrm{~m} / \mathrm{s}$, what is possible in the case of electrical wheelchair and for wheelchair with assistance.

The fact that is very important to note is that all of mobile occupants had the same speed and all of immobile occupants (wheelchairs) had the same speed and that is something with little probability in real. Also, the potentials for falls and tumbles in simulations were disabled and those situations can significantly change the evacuation time and evacuation progress in real. 


\section{CONCLUSION}

The usage of simulation software in evacuation prediction presents very important, effective, relative precise, safe and financially cheap method. Perhaps it can always give precise results in sense of total evacuation time calculation because it can't regard all of variables and influences (panic, fear, pain and lot of other) but, in any case, it can give the better vision of potential and optimal evacuation scenarios and participate in reduction of complete

\section{REFERENCES}

1. Glavinić P, Rasković Đ. Manual for preparation of candidats for professional exam from fire protection field. Meritus tim, ISBN 978-86-917589-91, Fourth edition, pp. 241, 242, 2016, Beograd.

2. Jevtić BR. The importance of fire simulation in fire prediction. Tehnika elektrotehnika, Vol 1., pp. 153-158, ISSN 0040-2176, Beograd, Serbia, 2014.

3. Jevtić BR, Ničković TJ. Object evacuation for different speeds of occupants, $58^{\text {th }}$ ETRAN CONFERENCE, Vrnjačka Banja, Serbia, 2014.

4. Jevtić BR. The simulation of sanitary objects evacuation-an example of hotel radon in Niška Banja. Tehnika Elektrotehnika, Vol 3., pp. 545-550, ISSN 0040-2176, Beograd, Serbia, 2015.

5. https://www.thehindubusinessline.com/ multimedia

6. https://www.news.com.au/world/middleeast

7. https://www.blic.rs/vesti/svet/zemljotresrazorio-meksiko-zgrade-padaju-kao-odsale-poginulo-najmanje-248-ljudi-medu/ cgpd8yp evacuation time. It is particularly important for some situations that are very hard to realize in experimentally sense because of complexity, technical problems or danger for people that take part in experimental testing. This paper also presents a good example and base for future investigation for, as an example, evacuation patients in medical beds, evacuation of more different types of immobile patients and in usage of some new methods in evacuations mobile and immobile occupants from different sanitary objects. ${ }^{(12-16)}$
8. https://www.thehindu.com/sci-tech/ energy-and-environment/New-fault-inIndian-Ocean-may-trigger-quakes-in-futurestudy/article17013186.ece

9. Thunderhead, Pathfinder Exmple Guide, USA, 2018.

10. Wilson L. Planning for evacuating people with disability. International Fire Protection Magazine, Issue 61, pp. 48-50. , March 2015.

11. Babić B. Evakuacija i spasavanje. Visoka tehnička škola strukovnih studija u Novom Sadu, pp. 27, 28, Novi Sad, 2012.

12. https://www.safety.rochester.edu/fire/ PatientEvac.html

13. http://www.hcpro.com/SAF-224575$877 / \mathrm{New}$-evacuation-method-for-immobilepatients.html

14. https://www.ncbi.nlm.nih.gov/ pubmed/11693042

15. https://ops.fhwa.dot.gov/publications/ fhwahop09022/fhwahop09022.pdf

16. Wilson L. Evacuation of People with Disability \& Emergent Limitations: Considerations for Safer Buildings \& Efficient Evacuations. Edition 2.0, pp. 69-72, 76, 88-92 July 2016.

Contact: Dr Radoje Jevtić, ETŠ „Nikola Tesla“, Aleksandra Medvedeva 18, 18000 Niš, Srbija, Phone: +381 63759019 3; +381 8028 162, E-mail: milan.jvtc@gmail.com 